\title{
Aandacht voor techniek in het medisch onderwijs is broodnodig voor kwalitatief hoogstaande en veilige zorg
}

\author{
G.J. Verkerke, W.M. Molenaar
}

De huidige medicus kan niet meer zonder techniek. De afhankelijkheid van apparatuur is erg groot geworden. Zo vereist alleen al het aanbrengen van een hechting technische hulpmiddelen zoals de hechtnaald (een technisch product, gemaakt van roestvast staal) en het hechtdraad (dat beschikbaar is in niet-oplosbare en oplosbare versies en zelfs met weerhaakjes, die voor een betere grip zorgen). Ook voor het stellen van een diagnose is veel apparatuur beschikbaar, variërend van een (digitale) bloeddrukmeter tot een PET-scanner, die processen zichtbaar maakt met radioactief gelabelde stoffen. Het therapeutisch arsenaal varieert van pleisters, die in vele materialen beschikbaar zijn (zelfs een versie, waarmee de wond vochtig kan blijven en daardoor sneller zal genezen) tot een kunsthart, dat een patiënt weer ambulant maakt. Echter, steeds vaker wordt gerapporteerd over fouten in de diagnostiek en in de behandeling van patiënten, die te wijten zijn aan een falend gebruik van technische hulpmiddelen, zoals het verkeerd instellen van infuuspompen, of een verkeerd gebruik van tilliften.

Om deze fouten in aantal te verminderen, is training een eerste vereiste. Maar voor een goed gebruik van technische apparatuur en voor het goed kunnen volgen van de training is enige technische kennis en begrip onontbeerlijk. Ook de minister ${ }^{1}$ en de inspecteur-generaal voor de $\mathrm{Ge}$ zondheidszorg ${ }^{2}$ willen meer techniek in het medisch curriculum om het aantal ongevallen, waarbij falend gebruik van techniek een hoofdrol speelt, te verminderen.
Een tweede argument voor meer techniek in de opleiding geneeskunde is het gegeven dat met de toenemende technologie in de geneeskunde ook het aantal opleidingen dat zich richt op het opleiden van professionals met kennis en vaardigheden op het gebied van technologie en zorg (TZ-professionals) is toegenomen. ${ }^{3}$ Voorbeelden hiervan zijn de opleidingen Biomedische Technologie, die ingenieurs opleiden in het toepassen van technische kennis voor het oplossen van medische problemen, en de opleiding Klinische Technologie/Technische Geneeskunde aan de Universiteit Twente, die een sterk accent legt op de geneeskunde. Deze TZprofessionals zullen gaan samenwerken met medici. Daar de culturen van technici en medici zeer verschillend zijn, zal de samenwerking aanzienlijk vereenvoudigd kunnen worden als medici enige kennis van techniek en van de technische cultuur verworven hebben.

In de huidige opleidingen geneeskunde is onderwijs in techniek echter zeer beperkt aanwezig of zelfs volledig afwezig. Ook is het niet opgenomen in het huidige Raamplan voor de artsopleiding. ${ }^{4}$ Dit heeft twee redenen. Allereerst is het niet mogelijk om alle geneeskundige onderwerpen te onderwijzen, met als gevolg dat het inbouwen van techniekvakken in het curriculum een lage prioriteit heeft. Daarnaast hebben studenten grote moeite om techniekvakken succesvol af te ronden.

Dat het heel goed mogelijk is om techniek in het curriculum geneeskunde in te bouwen, is te zien bij onze buren in België 
waar in de opleiding geneeskunde veel meer onderwijs in techniek is opgenomen. Het stigma dat techniek een struikelvak is, ligt vaak aan een disbalans tussen verwachte en aanwezige voorkennis van de studenten. Docenten (veelal fysici) zullen daarom hun vakinhoud niet alleen moeten aanpassen aan de specifieke voorkennis van studenten geneeskunde, maar ook aan hun specifieke denkwijze, die anders is dan die van techniek-studenten. Anderzijds zullen ook medici de rol van techniek binnen de geneeskunde duidelijker moeten maken en aangeven dat techniek een belangrijke bijdrage aan diagnostiek en therapie levert. Gezien de grote aanwezigheid van techniek zijn er voldoende voorbeelden voorhanden. Het technisch onderwijs moet zich richten op

- het zichtbaar maken van de mogelijkheden van (medische) techniek,

- het geven van inzicht in de faalbaarheid van techniek,

- het doordacht omgaan met techniek,

- het correct interpreteren van meetgegevens,

- het geven van inzicht in medisch-technische opleidingen en beroepen (Opleiding Biomedische Technologie, Technische Geneeskunde, Klinische Fysica).

Concluderend pleiten wij ervoor dat de geneeskunde- en technische opleidingen samen een basispakket 'medische techniek' ontwikkelen met als doel studenten geneeskunde meer inzicht te geven in medisch-technische toepassingen op een voor hen aansprekende wijze. Op deze wijze zal techniek geen struikelvak meer zijn, maar een nuttig en zelfs onmisbaar onderdeel van de opleiding geneeskunde en een goede basis vormen voor verder specialistische differentiatie. Een positief neveneffect is dat medici met begrip voor techniek een betere bijdrage kunnen leveren aan verdere technologische ontwikkelingen doordat ze beter kunnen samenwerken met technici.

\section{Literatuur}

1. Klink A. Staat van de Gezondheidszorg 2008, 2009. http://www.minvws.nl/kamerstukken/gmt/ 2009/staat-van-de-gezondheidszorg-2008.asp [Inspectorate of Health Care 2008, 2009].

2. Inspectie voor de gezondheidszorg. Staat van de gezondheidszorg 2008: risico's van medische technologie onderschat, 2008.http://www.igz.nl/ 34044/1534229/2008-10_Staat_van_de_Gezond 1.pdf [Inspectorate of Health Care. The state of health care 2008: the risks of medical technology are underestimated].

3. Commissie Technologie, zorg en opleidingen. Techniek met zorg, 2004. http://www.minvws.nl/ rapporten/ibe/2004/techniek-met-zorg.asp [Technology Commission, care and training programmes. Technology with care, 2004].

4. Herwaarden CLA van, Laan RFJM, Leunissen RRM. Raamplan Artsopleiding 2009. Nederlandse Federatie van Universitair Medische Centra, 2009. http://www.nfu.nl/fileadmin/documents/Raamplan_Artsopleiding_2009.pdf [The 2009 Framework for undergraduate medical education 2009. Dutch Federation of University Medical Centres, 2009].

\section{De auteurs:}

Prof. dr. ir. G.J. Verkerke is hoogleraar Biomedische Productontwikkeling en werkzaam in het Universitair Medisch Centrum Groningen.

Prof. dr. W.M. Molenaar is hoogleraar Medisch Onderwijs, in het bijzonder wetenschappelijke vorming, en werkzaam bij het Onderwijsinstituut van het Universitair Medisch Centrum Groningen.

\section{Correspondentieadres:}

Prof. dr. ir. G.J. Verkerke, afd. Biomedical Engineering, UMCG, postbus 196, 9700 AD Groningen. Tel.: 0503633126; e-mail: g.j.verkerke@med.umcg.nl

Belangenconflict: geen gemeld

Financiële ondersteuning: geen gemeld 